\title{
Subclinical ischaemic episodes during the steady state of sickle cell anaemia
}

\author{
N O Akinola, S M E Stevens, I M Franklin, G B Nash, J Stuart
}

Department of

Haematology, Medical School, The University of Birmingham,

Birmingham B15 2TT

N O Akinola

S M E Stevens

I M Franklin

G B Nash

J Stuart

Correspondence to:

Professor J Stuart

Accepted for publication

28 April 1992

\begin{abstract}
Aims: To determine the clinical, haematological, biochemical and rheological changes that occur in the asymptomatic steady state of sickle cell anaemia.

Methods: Patient self-assessment visual analogue scores (for wellbeing and tiredness), the blood concentration of acute phase proteins (C-reactive protein, orosomucoid, and fibrinogen), and blood rheology (percentage of dense cells and the number of sickled cells that occluded pores $5 \mu \mathrm{m}$ in diameter) were studied longitudinally on 10 occasions in each of 20 outpatients with sickle cell anaemia.

Results: Patients in the steady state showed fluctuation in visual analogue scores, in concentration of acute phase proteins, and in rheological parameters consistent with minor episodes of tissue injury. Significantly more variation in acute phase proteins occurred in the steady state of 14 of the 20 patients who developed one or more vaso-occlusive crises during the 16 month study period. Rheological fluctuation in the steady state simulated rheological change during crisis, namely a transient rise and then fall in the number of dense and poorly filterable cells.

Conclusions: The term "steady state" is a misnomer, being characterised by biochemical and rheological fluctuation consistent with minor episodes of microvascular occlusion that are insufficient to cause the overt tissue infarction of painful crisis.
\end{abstract}

(F Clin Pathol 1992;45:902-906)
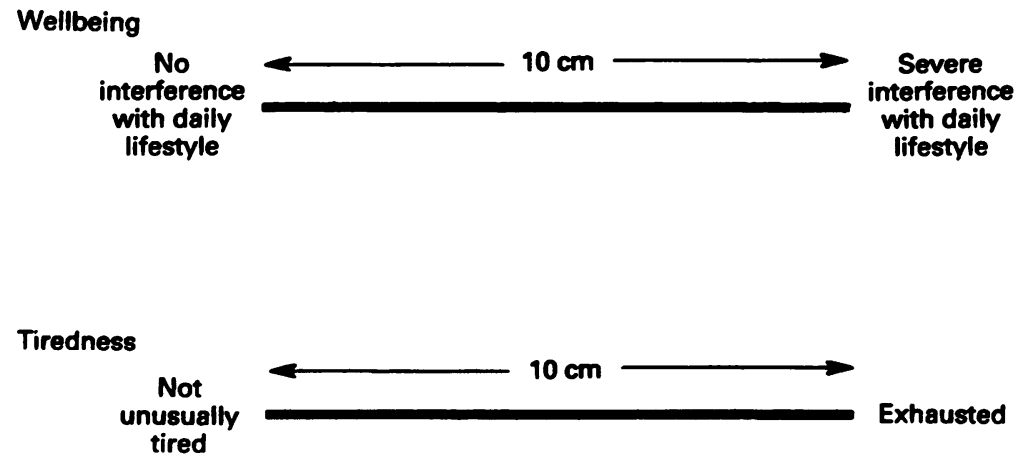

Figure 1 Visual analogue scales for patient self assessment of wellbeing and tiredness during the steady state.
Patients with sickle cell anaemia sustain intermittent vaso-occlusive (painful) crises. The period between crises is known as the asymptomatic steady state, although this clinical description may be inaccurate as episodes of minor pain that respond to simple analgesics are common in some patients. ${ }^{1}$ Rheological studies made in the steady state to investigate factors that may precipitate crisis have shown considerable heterogeneity among patients in blood yield stress, ${ }^{2}$ erythrocyte deformability, ${ }^{3}$ erythrocyte adhesion to endothelium, ${ }^{4}$ percentage of dense cells, ${ }^{56}$ and in red cell distribution width. ${ }^{7}$ This heterogeneity limits the value of cross-sectional studies and thus longitudinal studies of the relation between clinical events and change in rheological parameters may be more informative.

An earlier longitudinal study of six patients in the steady state showed fluctuation with time in the filterability of sickle cells through pores of $5 \mu \mathrm{m}$ in diameter. ${ }^{3}$ Erythrocyte filterability has subsequently been shown to be highly sensitive to the presence of subpopulations of poorly deformable sickle cells, ${ }^{8}$ particularly dense dehydrated cells ${ }^{9}$ that are sensitive to the formation of small amounts of intracellular polymer. ${ }^{1011}$ Dense cells have been shown to contribute disproportionately to impairment of blood flow in the microcirculation. ${ }^{12}$ Fluctuation in the number of these cells in the steady state may therefore contribute to the development of clinical events. Alternatively, such fluctuation may merely be secondary to clinically silent vaso-occlusive episodes.

\section{Methods}

The 20 patients with sickle cell anaemia were regular attenders at the sickle cell clinic and gave informed consent to the study which was approved by the local research ethical committee. Each patient was taught to keep a diary of clinical events and mark visual analogue scales (VAS) for wellbeing and tiredness (fig 1). The patients were visited at home more or less monthly by a nurse practitioner to check the diaries, supervise completion of the VAS assessment, and to obtain $30 \mathrm{ml}$ of blood. A mean of 10 such visits (range nine to 11 ) was made during asymptomatic periods.

The steady state was defined as the period free of crisis extending from at least three weeks since the last clinical event and three months or more since the last blood transfusion, to at least one week before the start of a new clinical event.

Blood samples were obtained from non- 
Table 1 Mean (SD) steady state values, reference (normal) range for healthy adults, and relative variation (CV\%) with time in 20 patients studied

\begin{tabular}{|c|c|c|c|}
\hline Parameter & Mean (SD) & $\begin{array}{l}\text { Reference } \\
\text { range }\end{array}$ & $\begin{array}{l}\text { Relative } \\
\text { variation }(C V \%)\end{array}$ \\
\hline $\begin{array}{l}\text { Clinical: } \\
\text { VAS wellbeing } \\
\text { VAS tiredness }\end{array}$ & $\begin{array}{l}2.0(1.6) \\
2.7(1.9)\end{array}$ & $\begin{array}{l}0 \\
0\end{array}$ & $\begin{array}{l}81 \cdot 9 \\
59 \cdot 8\end{array}$ \\
\hline $\begin{array}{l}\text { Acute phase } \\
\text { CRP (mg/l) } \\
\text { Orosomucoid }(\mathrm{g} / \mathrm{l}) \\
\text { Fibrinogen }(\mathrm{g} / \mathrm{l})\end{array}$ & $\begin{array}{l}8.0(6 \cdot 0) \\
0.9(0 \cdot 2) \\
3.6(0.8)\end{array}$ & $\begin{array}{r}<10 \\
0 \cdot 5-1 \cdot 4 \\
1 \cdot 5-4 \cdot 0\end{array}$ & $\begin{array}{l}71 \cdot 6 \\
19 \cdot 4 \\
14 \cdot 7\end{array}$ \\
\hline $\begin{array}{l}\text { Biochemical: } \\
\operatorname{LDH}(\mathrm{U} / \mathrm{l})\end{array}$ & 875 (256) & $230-460$ & $12 \cdot 4$ \\
\hline $\begin{array}{l}\text { Haematological: } \\
\text { HDW (g/dl) } \\
\text { RDW }(\%)\end{array}$ & $\begin{array}{r}4.3(0.5) \\
21.9(1.4)\end{array}$ & $\begin{array}{c}2 \cdot 2-3 \cdot 2 \\
11 \cdot 5-14 \cdot 5\end{array}$ & $\begin{array}{l}4 \cdot 7 \\
3 \cdot 5\end{array}$ \\
\hline $\begin{array}{l}\text { Rheological: } \\
\text { Plasma viscosity (mPa.s) } \\
\text { Volume }<60 \mathrm{fl}(\%) \\
\text { Fraction } 4(\%) \\
\text { Clogging particles }\left(\times 10^{5} / \mathrm{ml}\right)\end{array}$ & $\begin{array}{c}1 \cdot 69(0 \cdot 1) \\
6 \cdot 0(3 \cdot 4) \\
38 \cdot 1(12 \cdot 7) \\
9 \cdot 2(3 \cdot 7)\end{array}$ & $\begin{aligned} & 1 \cdot 52-1 \cdot 71 \\
& 0 \cdot 1-6 \cdot 7 \\
< & 6 \% \\
< & 3 \cdot 0\end{aligned}$ & $\begin{array}{r}4 \cdot 0 \\
30 \cdot 5 \\
19 \cdot 6 \\
24 \cdot 9\end{array}$ \\
\hline
\end{tabular}

fasting subjects in the mornings and rheological tests were started within four hours according to the guidelines of the International Committee for Standardization in Haematology. ${ }^{13}$ Protein assays were performed on plasma or serum which had been stored at $-20^{\circ} \mathrm{C}$.

Serum C-reactive protein (CRP) was measured by enhanced latex agglutination (Cobas Bio analyzer; Roche Diagnostics, Welwyn Garden City); serum orosomucoid ( $a_{1}$-acid glycoprotein) and plasma fibrinogen antigen using radial immunodiffusion kits (The Binding Site Ltd, Birmingham); plasma viscosity at $25^{\circ} \mathrm{C}$ by Coulter Viscometer II (Coulter Electronics Ltd, Luton) ${ }^{14}$; and serum lactate dehydrogenase (LDH) by automated enzyme assay (Hitachi 717; Boehringer Mannheim UK, Lewes). Blood counts, including red cell distribution width (RDW), haemoglobin distribution width (HDW), and the percentage of red cells of volume of less than $60 \mathrm{fl}$ were performed by Technicon H1 analyser (Bayer Diagnostics UK Ltd, Basingstoke).

Percoll (9 parts) and sodium diatrizoate $(50 \% \mathrm{w} / \mathrm{v} ; 2$ parts) discontinuous density gradients were modified from Mackie $e t a^{15}$ by diluting with phosphate buffered saline to give concentrations (densities) of $52 \% \mathrm{v} / \mathrm{v}$ $(1.084 \mathrm{~g} / \mathrm{ml}), \quad 60 \% \mathrm{v} / \mathrm{v} \quad(1.096 \mathrm{~g} / \mathrm{ml})$, and $66 \% \mathrm{v} / \mathrm{v}(1 \cdot 104 \mathrm{~g} / \mathrm{ml})$. Blood anticoagulated with heparin was first filtered through Imugard IG 500 cotton wool (Terumo Corporation, Tokyo, Japan) and washed twice in HEPES $(40 \mathrm{mmol} / \mathrm{l})$ buffered saline ${ }^{16}$ to give a pure suspension of sickle cells. ${ }^{17}$ This was applied at an haematocrit of $0.40 \mathrm{l} / 1$ to the top of the gradient in duplicate tubes before centrifugation at $450 \times g\left(40\right.$ minutes at $\left.12 \pm 2^{\circ} \mathrm{C}\right)$. Four fractions, including the reticulocyte rich layer on top of the gradient, were obtained and separated; identical fractions from duplicate tubes were then pooled. A red cell count was performed on each fraction and the percentage of bottom dense cells (fraction 4; F4) determined.

Erythrocyte deformability was measured as the number of clogging particles $\left(\times 10^{5} / \mathrm{ml}\right)$ that occluded the $5 \mu \mathrm{m}$ diameter pores of Hemafil polycarbonate membranes (Nuclepore Corporation, Pleasanton, California, USA). The study was performed using a small number of selected membranes (batch No 54B6A10) that were reused after cleaning by ultrasonication. ${ }^{18}$ Filtration measurements, of a pure suspension of washed unfractionated erythrocytes at a concentration of $0.15 \times$ $10^{12} / \mathrm{l}$, were made at $37^{\circ} \mathrm{C}$ using a St George's Filtrometer (Carri-Med Ltd, Dorking), ${ }^{19}$ as previously described. ${ }^{8}$ Quality control of filterability was performed daily using normal blood samples; $95 \%$ of these daily measurements during the 16 month study were within the mean and $2 \mathrm{SD}$ for 10 normal samples tested on one day using 10 different Hemafil membranes.

Significance was determined by the MannWhitney $U$ test (two tailed). The variation with time within all 20 patients was determined as the coefficient of variation $\left(\mathrm{CV}_{1}\right)$ for 10 serial estimations in the steady state, expressed as the mean for the 20 patients. This variation represents both biological variation and variation in the technical procedure (precision). Precision was determined as the $\mathrm{CV}$ for 10 replicate measurements within a batch $\left(\mathrm{CV}_{2}\right)$. The biological variation adjusted for precision (relative variation) was then calculated using the formula:

$$
\text { relative variation }=\sqrt{\left(\mathrm{CV}_{1}\right)^{2}-\left(\mathrm{CV}_{2}\right)^{2}}
$$

Table 2 Mean (SD) steady state values and relative variation (CV\%) with time in 14 patients who did, and six who did not, develop a vaso-occlusive crisis

\begin{tabular}{|c|c|c|c|c|c|c|}
\hline & \multicolumn{3}{|l|}{ Mean $(S D)$} & \multicolumn{3}{|c|}{ Relative variation ( $\mathrm{CV} \%)$} \\
\hline & Crisis $(n=14)$ & No crisis $(n=6)$ & p Value & Crisis $(n=14)$ & No crisis $(n=6)$ & p Value \\
\hline $\begin{array}{l}\text { Clinical: } \\
\text { VAS wellbeing } \\
\text { VAS tiredness }\end{array}$ & $\begin{array}{l}2 \cdot 4(1 \cdot 8) \\
3 \cdot 1(2 \cdot 0)\end{array}$ & $\begin{array}{l}1.0(0.5) \\
1.7(1.4)\end{array}$ & $\begin{array}{l}\text { NS } \\
\text { NS }\end{array}$ & $\begin{array}{l}87 \cdot 5 \\
66 \cdot 6\end{array}$ & $\begin{array}{l}76 \cdot 5 \\
59 \cdot 5\end{array}$ & $\begin{array}{l}\text { NS } \\
\text { NS }\end{array}$ \\
\hline $\begin{array}{l}\text { Acute phase: } \\
\text { CRP (mg/l) } \\
\text { Orosomucoid }(\mathrm{g} / \mathrm{l}) \\
\text { Fibrinogen }(\mathrm{g} / \mathrm{l})\end{array}$ & $\begin{array}{l}8 \cdot 9(7 \cdot 1) \\
0 \cdot 9(0 \cdot 2) \\
3 \cdot 7(0 \cdot 8)\end{array}$ & $\begin{array}{l}5 \cdot 3(2 \cdot 2) \\
0 \cdot 7(0 \cdot 1) \\
3 \cdot 5(0 \cdot 8)\end{array}$ & $\begin{array}{l}\text { NS } \\
<0 \cdot 05 \\
\text { NS }\end{array}$ & $\begin{array}{l}71 \cdot 2 \\
19 \cdot 6 \\
13 \cdot 8\end{array}$ & $\begin{array}{l}39 \cdot 8 \\
11 \cdot 4 \\
10 \cdot 2\end{array}$ & $\begin{array}{l}<0.05 \\
<0.05 \\
\text { NS }\end{array}$ \\
\hline $\begin{array}{l}\text { Biochemical: } \\
\text { LDH (U/l) }\end{array}$ & $901(254)$ & $813(275)$ & NS & $12 \cdot 2$ & $8 \cdot 7$ & NS \\
\hline $\begin{array}{l}\text { Haematological: } \\
\text { HDW (g/dl) } \\
\text { RDW }(\%)\end{array}$ & $\begin{array}{r}4 \cdot 1(0.5) \\
22 \cdot 3(1 \cdot 4)\end{array}$ & $\begin{array}{r}4.5(0.5) \\
20.9(0.9)\end{array}$ & $\begin{array}{l}\text { NS } \\
<0.05\end{array}$ & $\begin{array}{l}3.5 \\
3.7\end{array}$ & $\begin{array}{l}5 \cdot 1 \\
2 \cdot 6\end{array}$ & $\begin{array}{l}\text { NS } \\
<0.05\end{array}$ \\
\hline $\begin{array}{l}\text { Rheological: } \\
\text { Plasma viscosity (mPa.s) } \\
\text { Volume <60 f ( }(\%) \\
\text { Fraction } 4(\%) \\
\text { Clogging particles }\left(\times 10^{5} / \mathrm{ml}\right)\end{array}$ & $\begin{array}{c}1 \cdot 7(0 \cdot 1) \\
6 \cdot 7(3 \cdot 6) \\
39 \cdot 8(12 \cdot 8) \\
8 \cdot 7(3 \cdot 5)\end{array}$ & $\begin{aligned} 1 \cdot 7 & (0 \cdot 1) \\
4 \cdot 3 & (2 \cdot 2) \\
34 \cdot 1 & (12 \cdot 4) \\
10 \cdot 4 & (4 \cdot 2)\end{aligned}$ & $\begin{array}{l}\text { NS } \\
\text { NS } \\
\text { NS } \\
\text { NS }\end{array}$ & $\begin{array}{r}4 \cdot 1 \\
32 \cdot 1 \\
15 \cdot 9 \\
23 \cdot 8\end{array}$ & $\begin{array}{r}2 \cdot 8 \\
24 \cdot 3 \\
25 \cdot 0 \\
23 \cdot 8\end{array}$ & $\begin{array}{l}\text { NS } \\
\text { NS } \\
<0 \cdot 05 \\
\text { NS }\end{array}$ \\
\hline
\end{tabular}


Figure $2(A-D)$ Examples from four patients of serial values for percentage dense cells (fraction 4) (O) and clogging particles ( $\square$ ) during the steady state. Insert shows percentage change during

vaso-occlusive crisis compared with the mean of all steady state values expressed as $100 \%$.

\section{Results}

Confirmation of the steady state was obtained from the patient diaries and by the patients' absence at the sickle clinic or ward. Despite confirmation of what is conventionally regarded as the asymptomatic state, the VAS scores for wellbeing and tiredness showed considerable fluctuation with time (table 1). Also, the rapidly responding acute phase protein CRP gave a high $\mathrm{CV}$ for relative variation while the slower responding acute phase proteins orosomucoid and fibrinogen and serum LDH showed less variation with time. The haematological parameters HDW and RDW showed

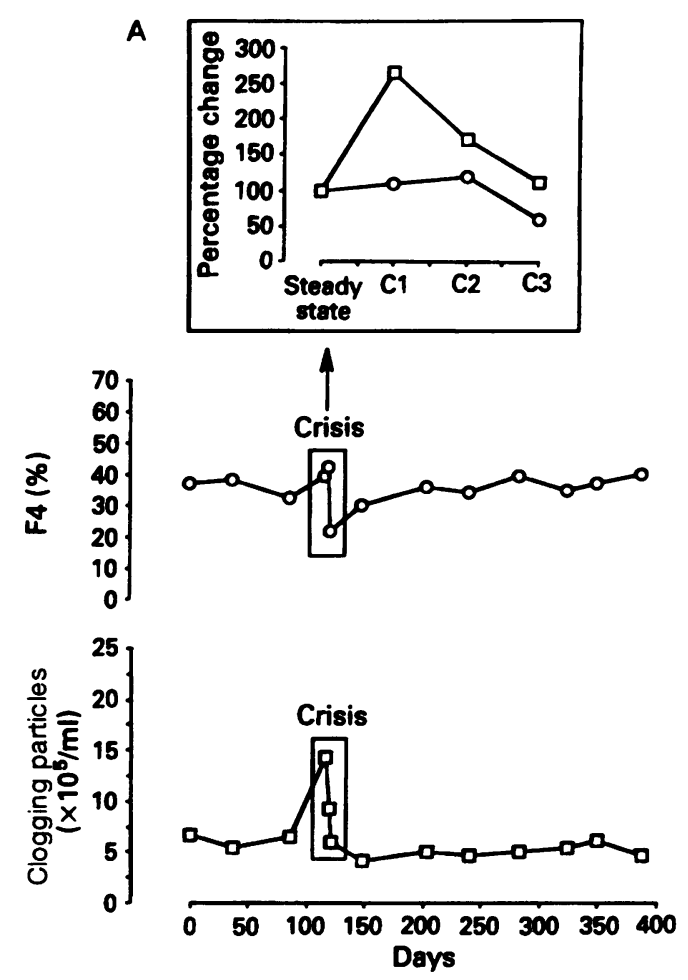

C

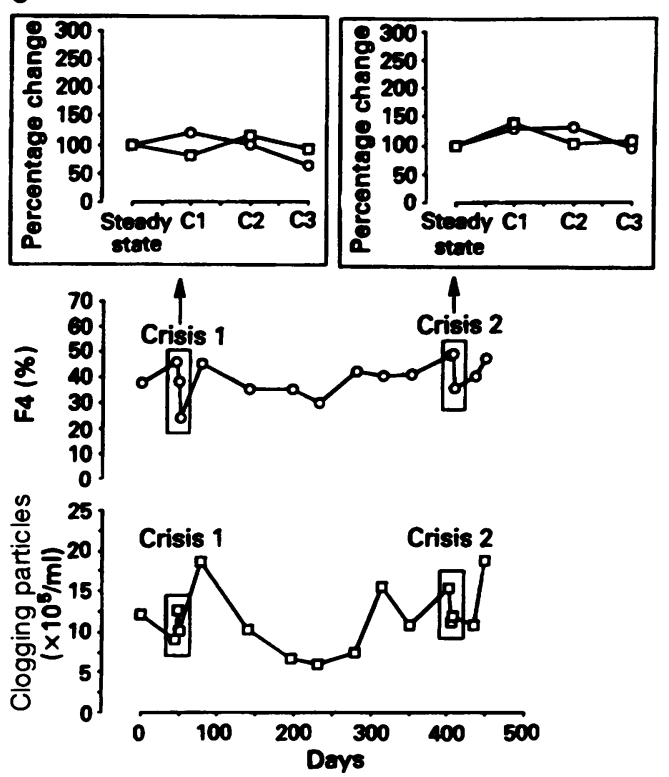

little variation with time, as did plasma viscosity, but erythrocyte rheology (cells of volume less than $60 \mathrm{fl}$, clogging particles, and dense cells) showed substantial variation (table 1).

Fourteen of the 20 patients sustained one or more vaso-occlusive crises during the 16 month study. Orosomucoid and RDW showed a significantly higher $(p<0.05)$ steady state mean value for the 14 patients (table 2), compared with the six who had no crisis, but the difference was small and the other parameters showed no significant difference. Patients who developed a crisis, compared with
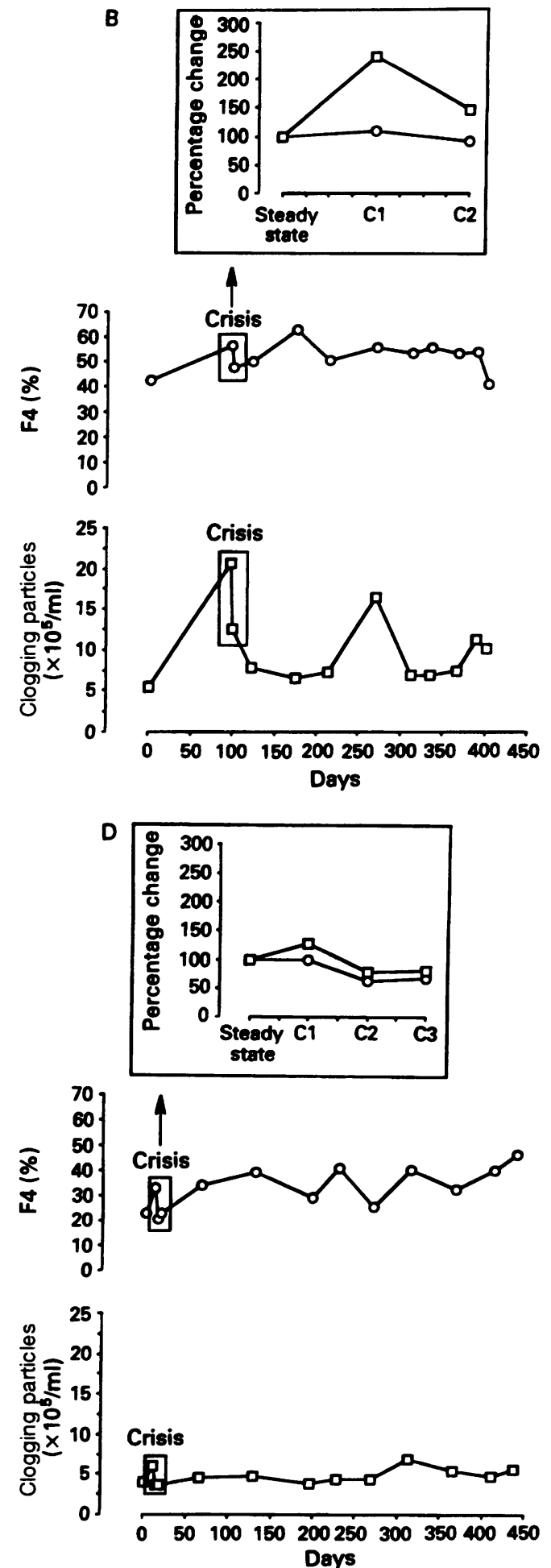
those who did not, showed significantly $(\mathrm{p}<0.05)$ more fluctuation with time in C-reactive protein and orosomucoid and less fluctuation in the percentage of dense cells (table 2). At the $5 \%$ level of significance, at least one of the 24 comparisons made in table 2 would be expected to be significantly different by chance.

When rheological results for individual patients were plotted to show the temporal relation between change in rheological parameters and the occurrence of a crisis, most patients showed an increase in the number of clogging particles and percentage of dense cells at the onset of crisis (figs 2A-D), as detailed elsewhere. ${ }^{20}$ Several patients, however, showed as large a fluctuation in erythrocyte rheology during the steady state as in crisis (figs 2 B-D).

\section{Discussion}

Visual analogue scores for wellbeing and tiredness showed considerable fluctuation with time, as did the fast reacting acute phase protein CRP which can show a rise in blood concentration within six to 10 hours of an inflammatory stimulus and subsides with a half time of 48 hours. $^{21}$ The slower responding acute phase proteins orosomucoid and fibrinogen (rise in blood concentration within 24-48 hours which subsides with a half time of four to six days) ${ }^{21}$ and serum LDH, which is increased in the steady state and is further increased during vaso-occlusive crisis, ${ }^{22}$ showed only moderate variation with time. These results are consistent with minor episodes of tissue injury that resolve quickly, this being supported by the modest rise in CRP (maximum value recorded $57 \mathrm{mg} / \mathrm{l}$ ) that occurred during the steady state compared with the greater increase that occurs in vaso-occlusive crisis (mean value $65.7 \mathrm{mg} / \mathrm{l}$ ) and SD 90.7 on days 3 to 5$).^{20}$

Of the rheological tests, plasma viscosity showed little variation with time whereas tests of erythrocyte rheology showed substantial fluctuation. The filtration technique used to study erythrocyte rheology (clogging of $5 \mu \mathrm{m}$ pores in the St George's Filtrometer) is particularly sensitive to the presence of subpopulations of poorly deformable dense cells. $^{89}$ At the onset of crisis, there was a transient increase in the percentage of dense cells and loss of filterability of unfractionated sickle cells. ${ }^{20}$ These changes reverse as crisis evolves, ${ }^{202324}$ consistent with entrapment and removal of rheologically compromised dense cells in occluded areas of the microcirculation. ${ }^{12}$ Rheological changes in the steady state therefore simulate those of crisis and may be quantitatively larger or smaller.

In a previous study of the steady state Fabry et $a l^{24}$ who studied six patients on an average of 3.8 occasions over 14 months, detected little change (within $\pm 7 \%$ ) in the percentage of dense cells with time. In contrast, in a longitudinal study of the steady state, Morris et al found substantial variation in yield stress with time which was explained by differences in cell density. Ballas also found variation (mean CV
$25.0 \%$ ) in the number of dense cells (mean $22 \cdot 2 \%$ ) over a three year period within 10 patients who had low red cell deformability. ${ }^{25}$ In our 20 patients in the steady state dense cells (CV 19.6\%) and the filterability of unfractionated sickle cells (CV 24.9\%) fluctuated considerably with time. Variation in these parameters with time presumably depends on the balance between formation of dense, poorly deformable cells, and their destruction in the circulation or reticuloendothelial system. In the steady state this balance is estimated to produce sufficient circulating dense sickled cells to block a significant fraction of the total number of capillaries. $^{26}$

The term "steady state" therefore seems to be a misnomer, with the formation of dense cells exceeding their destruction-that is, dense cells and clogging particles increasinguntil a crisis or sub-clinical episode of vascular occlusion causes a period of rapid removal. The factors that determine whether the increase in dense cells leads to a crisis or the less severe symptoms of the steady state remain uncertain.

The 14 patients who developed a crisis showed, in the steady state, significantly greater variation in CRP and orosomucoid than the six patients who had no crisis. Conversely, these 14 patients showed less variation in dense cells. The greater variation in acute phase proteins suggests that patients with crisis had more silent episodes of vaso-occlusion in the steady state which may have suppressed fluctuation in the percentage of dense cells. When the mean steady state values were calculated for all 20 patients, there was no significant correlation between the number of dense cells (or clogging particles), acute phase proteins (CRP and orosomucoid), and clinical state (visual analogue scores).

In summary, biochemical and rheological changes in the steady state are consistent with minor episodes of microvascular stasis. These episodes were insufficient to cause overt vasoocclusive crisis. Further longitudinal studies are required to determine the factors that precipitate rheological instability and the greater degree of tissue ischaemia of painful crisis.

We are indebted to The Wellcome Trust and the United Birmingham Hospitals Trust Funds for research grants; to the Department of Clinical Chemistry, General Hospital, Birmingham for serum LDH assays, and the Department of Haematology, Dudley Road Hospital, Birmingham for Technicon $\mathrm{H} 1$ blood counts; and to the patients whose regular donation of blood samples made this study possible.

1 Pearson HA, Wethers D, Johnson S. Pain in sickle cell disease. N Engl ₹ Med 1991;325:1748.

2 Morris CL, Gruppo RA, Shukla R, Rucknagel DL. Influence of plasma and red cell factors on the rheologic properties of oxygenated sickle blood during clinical steady state. F Lab Clin Med 1991;118;332-42.

3 Lucas GS, Caldwell NM, Stuart J. Fluctuating deformability of oxygenated sickle erythrocytes in the asymptomatic state and in painful crisis. $\mathrm{Br} f$ Haematol 1985;59:363-8.

4 Hebbel RP, Boogaerts MAB, Eaton JW, Steinberg MH. Erythrocyte adherence to endothelium in sickle-cell anemia. A possible determinant of disease severity. $N$ Engl f Med 1980;302:992-5.

5 Fabry ME, Nagel RL. Heterogeneity of red cells in the sickler: a characteristic with practical clinical and pathophysiological implications. Blood Cells 1982;8:9-15. 
6 Billett HH, Kim K, Fabry ME, Nagel RL. The percentage of dense red cells does not predict incidence of sickle cell of dense red cells does not predict inci

7 Thame M, Grandison Y, Mason K, et al. The red cell distribution width in sickle cell disease-is it of clinical distribution width in sickle cell disease-

8 Stäubli M, Stone PCW, Straub PW, Stuart J. Evaluation of methods for measuring erythrocyte deformability. Clin Hemorheol 1986;6:589-602.

9 Nash GB, Boghossian S, Parmar J, Dormandy JA, Bevan D. Alteration of the mechanical properties of sickle cells by repetitive deoxygenation: role of calcium and the effects of calcium blockers. Br 7 Haematol 1989;72:260-4.

10 Keidan AJ, Sowter MC, Johnson CS, et al. Effect of polymerization tendency on haematological, rheological
and clinical parameters in sickle cell anaemia. $\mathrm{Br} f$ Haematol 1989;71:551-7.

11 Keidan. AJ, Noguchi CT, Player M, Chalder SM, Stuart J. Erythrocyte heterogeneity in sickle cell disease: effect of deoxygenation on intracellular polymer formation and rheology of sub-populations. $\mathrm{Br} \quad \mathcal{f}$ Haematol 1989;72:254-9.

12 Kaul DK, Fabry ME, Windisch P, Baez S, Nagel RL. Erythrocytes in sickle cell anemia are heterogeneous in their rheological and hemodynamic characteristics. $f$ Clin Invest 1983;72:22-31.

13 International Committee for Standardization in Haematology. Expert Panel on Blood Rheology. Guidelines for measurement of blood viscosity and erythrocyte deformability. Clin Hemorheol 1986;6:439-53.

14 Cooke BM, Stuart J. Automated measurement of plasma viscosity by capillary viscometer. $\mathcal{f}$ Clin Pathol 1988; 41:1213-6.

15 Mackie LH, Frank RS, Hochmuth RM. Erythrocyte density separation on discontinuous "Percoll" gradients. Bio;24:227-30.

16 Keidan AJ, Sowter MC, Marwah SS, Johnson CS, Stuart J. Evaluation of HEPES and phosphate buffers for
rheological studies of sickle cells. Clin Hemorheol rheological studies

17 Stuart J, Stone PCM, Bareford D, Caldwell NM, Davies JE, Baar S. Evaluation of leucocyte removal methods for studies of erythrocyte deformability. Clin Hemorheol 1985;5:137-47.

18 Bilto YY, Stuart J. Ultrasonic cleaning of polycarbonate membranes for measurement of erythrocyte filterability. Clin Hemorheol 1985;5:437-48.

19 Dormandy J, Flute P, Matrai A, et al. The new St George's blood filtrometer. Clin Hemorheol 1985;5:975-83.

20 Akinola NO, Stevens SME, Franklin IM, Nash GB, Stuart $\mathrm{J}$. Rheological changes in the prodromal and established phases of sickle cell vaso-occlusive crisis. $\mathrm{Br} \mathcal{F}$ Haematol 1992;81:598-602.

21 International Committee for Standardization in Haematology (Expert Panel on Blood Rheology). Guidelines on ogy (Expert Panel on Blood Rheology). Guidelines on selection of laboratory tests for monitoring the

22 Neeley CL, Waijma T, Kraus AP, Diggs LW, Barreras L. Lactic acid dehydrogenase activity and plasma hemoglobin elevations in sickle cell disease. Am $\mathcal{f}$ Clin Pathol 1969;52:167-9.

23 Rieber EE, Veliz G, Pollack S. Red cells in sickle cell crisis: observations on the pathophysiology of crisis. Blood 1977;49:967-79.

24 Fabry ME, Benjamin L, Lawrence C, Nagel RL. An objective sign in painful crisis in sickle cell anemia: the concomitant reduction of high density red cells. Blood 1984;64:559-63.

25 Ballas SK. Sickle cell anemia with few painful crises is characterized by decreased red cell deformability and increased number

26 Eaton WA, Hofrichter J. Hemoglobin $S$ gelation and sickle cell disease. Blood 1987;70:1245-66. 